\title{
Growth, Fruiting, Yield and Nutritional Content of Okra Plant (Abelmoschus Esculentus (L.) Moench) as Influenced by Turmeric (Curcuma Longa) Extracts Spray
}

\author{
${ }^{1}$ OGBUEHI, H.C, ${ }^{1}$ AGBIM, J.U, ${ }^{2}$ UKAOMA, A.A
}

${ }^{1}$ Department of crop science and Biotechnolo Faculty of Agriculture, Imo State University, owerri ${ }^{2}$ Department of Biological Science, Federal University Technology, Owerri Imo State Nigeria

\begin{abstract}
The study was carried out to evaluate the effect of turmeric extract on growth and fruiting of Okra plant (Abelmoschus esculentum) at the teaching and Research Farm of Faculty of Agriculture and Veterinary Medicine, Imo State University, Owerri. The experiments were carried out in Randomized Complete Block Design. The treatments were aqueous and ethanol turmeric extract at different levels of concentration $(0,1 \%$, $2 \%$ and 3\%) replicated 3 times. The statistical result of the study indicated that aqueous turmeric extract improved the plant height, number leaf, stem girth, leaf area, and leaf area index than ethanol turmeric extract. The root and shoot dry weights were consistently improved by application of aqueous turmeric extract than ethanol extract. Analysis of nutritional status revealed that there was significant $(P<0.05)$ improvement in reduction of moisture content of Okra pod, improvement in protein, calcium, fibre, Ash and fat content by turmeric extract application. $T_{3}(2 \%)$ from aqueous and ethanol extract significantly $(P<0.05)$ produced higher yields $(385.60 \mathrm{~kg} / \mathrm{ha}$ and $390.733 \mathrm{~kg} / \mathrm{ha})$. These results thus showed that turmeric extract application of $200 \mathrm{ml}$ provided the better yield and nutritional status of Okra Crop.
\end{abstract}

Keywords: Growth, Fruiting, Okra Plant, Turmeric extract.

\section{INTRODUCTION}

Okra (Abelmoschus esculentus), is a herbaceous annual plant in the family Malvaeceae which is grown for its edible seed pods. Okra plants have small erect stems that can be bristly or hairless with heart-shaped leaves. The leaves are 10-20 cm (4-8 in) long with 5-7 lobes. The plant produces flowers with five white to yellow petals which are $4-8 \mathrm{~cm}(1.6-3.1 \mathrm{in})$ in diameter. The seed pod is a capsule up to $25 \mathrm{~cm}$ (10 in) long, containing numerous seeds. Okra can grow 1.2-1.8 m (4-6 ft) tall and as an annual plant, survives only one growing season. Okra may also be referred to as lady's fingers and is believed to have originated in Ethiopia (Westerfield, 2008).

Okra contains proteins, carbohydrates and vitamin-C (Owolarafe \& Shotonde, 2004; Gopalan et al., 2007; Arapitsas 2008; Dilruba et al., 2009), and plays a vital role in human diet (Kahlon et al., 2007; Saifullah \& Rabbani, 2009). Consumption of young immature okra pods is important as fresh fruits, and it can be consumed in different forms (Ndunguru \& Rajabu, 2004). Fruits can be boiled, fried or cooked (Akintoye et al., 2011).

The composition of okra pods per $100 \mathrm{~g}$ edible portion ( $81 \%$ of the product as purchased, ends trimmed) is: water $88.6 \mathrm{~g}$, energy $144.00 \mathrm{~kJ}$ (36 kcal), protein $2.10 \mathrm{~g}$, carbohydrate $8.20 \mathrm{~g}$, fat $0.20 \mathrm{~g}$, fibre $1.70 \mathrm{~g}, \mathrm{Ca} 84.00 \mathrm{mg}, \mathrm{P} 90.00 \mathrm{mg}, \mathrm{Fe} 1.20 \mathrm{mg}, \beta$-carotene $185.00 \mu \mathrm{g}$, riboflavin $0.08 \mathrm{mg}$, thiamin $0.04 \mathrm{mg}$, niacin $0.60 \mathrm{mg}$, ascorbic acid $47.00 \mathrm{mg}$ (Gopalan et al., 2007). The composition of okra leaves per $100 \mathrm{~g}$ edible portion is: water $81.50 \mathrm{~g}$, energy $235.00 \mathrm{~kJ}(56.00 \mathrm{kcal})$, protein $4.40 \mathrm{~g}$, fat $0.60 \mathrm{~g}$, carbohydrate $11.30 \mathrm{~g}$, fibre $2.10 \mathrm{~g}$, Ca $532.00 \mathrm{mg}, \mathrm{P} 70.00 \mathrm{mg}$, Fe $0.70 \mathrm{mg}$, ascorbic acid $59.00 \mathrm{mg}$, B-carotene $385.00 \mu \mathrm{g}$, thiamin $0.25 \mathrm{mg}$, riboflavin $2.80 \mathrm{mg}$, niacin $0.20 \mathrm{mg}$ (Varmudy, 2011). Carbohydrates are mainly present in the form of mucilage (Liu et al. 2005; Kumar et al., 2009).

Okra leaves are considered good cattle feed, but this is seldom compatible with the primary use of the plant. The leaf buds and flowers are also edible (Doijode, 2001). Moreover, okra mucilage is suitable for industrial and medicinal applications (Akinyele \& Temikotan, 2007). Industrially, okra mucilage 
is usually used for glace paper production and also has a confectionery use. Okra has found medical application as a plasma replacement or blood volume expander (Lengsfeld et al., 2004; Adetuyi et al., 2008; Kumar et al., 2010).

Yield decline is suggested to be a major problem that faces Okra growers in rain forest conditions. The main causes for poor yields are the great reduction of flowers and fruits retained on the plant as well as the great dropping of flower and fruitlets, unbalanced or malnutrition as well as unsuitable environmental conditions. Supplying the plant with their requirements from organic and mineral nutrients as well as using compounds increased the tolerance of trees to stresses is very beneficial for overcoming the yield reduction (Onuoha et al., 2013).

Since ancient times, plant extracts were used in many ways. Recently, public health and environmental safety concerns encouraged the use of these natural products as a complete replacement of chemicals for improving growth, nutritional status of plant. Their positive action on controlling pests is very essential. The content of natural extracts such as phenolic compounds, nutrients, plant pigments and other chemical constituents seem to have synergistic effects on growth and mortality of most fungus. Out of the important plant extracts are turmeric (Okigbo and Emoghene, 2003).

Turmeric, (Curcuma longa L.) is a herbaceous perennial plant belonging to the Zingiberaceous family. Curcuma genus contains about 30 species. It originated from India and South East Asia and cultivated in the majority of tropical countries. It is obtained from the rhizome of Curcuma longa. It contains 2 to $9 \%$ curcuminiods which contains $60 \%$ curcumin, desmethoxycurcumin, monodemethoxycurcumin, bisdemethoxycurcumin, dihydrocurcumin and cyclocurcumin. Cucumins oxidation yield vanillin. Tumeric extract is rich in carbohydrates, (50\% starch), arabinogalacton, potassium salt, essential oils and pigments. It is known for its anti- inflammatory, anti- oxidant and anti- microbial properties. Curcumin has a free radical scavenger activity namely hydroxyl radical that is responsible to protect DNA from damage and inhibit lipid peroxidation (Alonso, 2004).

This study is initiated to examine the effect of turmeric extracts on growth and fruiting of okra.

\section{Materials AND Methods}

\section{Location}

This study was conducted in the Teaching and Research Farm of the Faculty of Agriculture and Veterinary Medicine, Imo State University, Owerri. Owerri lies between the latitudes $5^{\circ} 10^{\prime} \mathrm{N}$ and $6^{\circ} 0^{\prime} \mathrm{N}$ and longitudes $6^{\circ} 35^{\prime} \mathrm{E}$ and $7^{\circ} 0{ }^{\prime} \mathrm{E}$ with an altitude of $91.0 \mathrm{~m}$ within the Southeast rain forest agricultural zone of Nigeria. The area maintains an average annual rainfall of $2,500 \mathrm{~mm}$, mean minimum and maximum temperature of $23.5^{\circ} \mathrm{C}$ and $32.1^{\circ} \mathrm{C}$ respectively, with relative humidity ranging from 70-85\% and the annual evapo transpiration is $1450 \mathrm{~mm}$ (NIMET, 2010).

\section{Source of Materials}

Materials to be used in this study were collected from Imo State University Teaching and Research Farm, while reagents to be used for extraction was also be purchased from the local market Okra seeds was sourced from NIHORT Okigwe. Other materials include, a piece of land measuring $15 \mathrm{~m} \mathrm{x}$ $18 \mathrm{~m}$, turmeric rhizomes, blender, weighing scale.

\section{Preparation of Turmeric Extract}

Dried turmeric was kept in a plastic zip bag at room temperature before extraction.

1. Cold solvent extraction method or maceration method (Vudhivanich \& Supanuntorn, 2005).Two extracts were used in this method.

A. Extraction with ethanol- Firstly, 300g of dried turmeric was soaked in $600 \mathrm{ml}$ ethanol, the mixtures was then filtered using a white handkerchief or a filter paper. Finally $1 \mathrm{~L}$ of distilled water was added to the filtrate to dilute the extract in order to obtain the different concentration which was collected and kept in a bottle at $4^{\circ} \mathrm{C}$ until use.

B. Extraction with water- $300 \mathrm{~g}$ of dried turmeric was soaked in $600 \mathrm{ml}$ water, the mixtures was then filtered with a handkerchief or filter paper. Then $1 \mathrm{~L}$ of distilled water was added to the filtrate to dilute the extract in order to obtain the different concentration which was collected and kept in a bottle at $4^{\circ} \mathrm{C}$ until use. 


\section{Experimental Design}

The experiment was laid out in a Randomized Complete Block Design in a split plot fashion. The extraction methods formed the main plots while the rate/concentration of application $(1 \%, 2 \%$ and $3 \%$ ) constitutes the subplots. The setup was replicated three times.

\section{Agronomic Practices and Treatment Application}

The experimental plot was cleared and low beds was made for planting. The okra seeds were planted at a depth of $2-3 \mathrm{~cm}$ with spacing of $45 \mathrm{~cm} X 50 \mathrm{~cm}$. The rate of seed sowing was two seeds per stand. This was later thinned down to one seedling per stand at two weeks after emergence and prior to treatment application.

The treatments were applied as specified at two weeks after planting, immediately after weeding and thinning and repeated at 4, 6, 8, 10 and 12 weeks at the rate of 20 ML per plant of the different concentration. The field was kept weed free throughout the study period.

\section{Data Collection and Analysis}

The following parameters were monitored and data were collected and recorded for analysis:

Plant height (cm): The height of selected plant from each plot was taken from the base of the plant to the tip in $\mathrm{cm}$ and recorded. This began at 2 weeks after planting (WAP) and repeated at 4, 6, 8, 10 and 12 WAP.

Stem Girth (cm): The girth of the selected plants was taken using a veneer-caliper and was recorded. This began at 2 weeks after planting (WAP) and repeated at 4, 6, 8, 10 and 12 WAP.

Number of Leaves/Plant: The visual count of number of leaves per plant was done on the plants and recorded. This began at 2 weeks after planting (WAP) and repeated 4, 6, 8, 10 and 12 WAP.

Leaf Area $\left(\mathbf{c m}^{2}\right)$ : The midrib length of 4 leaves of the selected plant was taken and calculated

Number of Fruits/Plant: Visual count of number of fruits per plant per harvest was taken and recorded. The average was be determined at the end of the study and recorded for analysis.

Leaf Area Index: The leaf area index of 1 selected plant from each treatment level was taken. The average was determined and recorded, this began at 2 weeks after planting and repeated at 4, 6, 8, 10, and 12 weeks after planting.

Fruit Yield (Kg/ha): The yield was measured according to the treatment and calculated using the formular,

$$
\frac{\text { Fresh weight } x 10,000}{\text { Land area [Umar Musa Tanko, 2015] }}
$$

Dry Weight: One plant was uprooted from each treatment level and the dry weight was determined. This began at 2 weeks after planting and repeated 4, 6, 8, 10 and 12 WAP.

Proximate Analysis: This was conducted to determine the nutritional contents as influenced by the treatments. (AOAC, 2000)

\section{Data Collection}

Data collected was subjected to statistical analysis, using the analysis of variance (ANOVA) of the SAS software 17.0 version. Means separation was done using the Least Significant Difference (LSD) method as described by Onuh and Igwemma, [2007].

\section{RESULTS}

\section{Effect of Treatment on Plant Height}

The result presented in table 1a, showed that turmeric extract increase the plant heights of the plant. Treated plots were found to have performed better than the control. However, the degree of performance was not significant compared to control especially at 2, 4, and 6 WAP. In Ethanol Extract, at $8 \mathrm{WAP}$ and $10 \mathrm{WAP}^{\mathrm{W}} \mathrm{T}_{3}-200 \mathrm{~g}$ significantly influence plant height $45.5 \mathrm{~cm}$ compared to control $27.17 \mathrm{~cm}$. The same trend was noticed at $10 \mathrm{WAP}$ and $12 \mathrm{WAP}$ respectively.

Whereas in Table $1 \mathrm{~b}$, the highest mean plant heights of $43 \mathrm{~cm} .65 \mathrm{~cm}$ and $85.17 \mathrm{~cm}$ respectively were recorded from plot treated with $200 \mathrm{~g}$ concentration at 8,10 , and 12 WAP which was significantly difference $(\mathrm{P}<0.05)$ from the main plant heights recorded from the untreated plots. 
However, among the treated plots, it was observed that $T_{3}-200 \mathrm{~g}$ concentration influenced the plant height compared to control and other treatment level in the extraction media.

\section{Effect of Treatment on Number of Leaves}

The number of leaves was not enhanced by both ethanol and water turmeric extract application at each of the sampling periods and there was no significant difference among the treatments (Table 2a-b).

However it was observed that control at 10 WAP and 12 WAP have more umber of leaves than other treatment levels respectively in both extraction methods.

\section{Effect of Treatment on Leaf Area $\left(\mathrm{cm}^{2}\right)$}

Application of turmeric extract influenced the leaf area at 8 WAP, 10 and 12 WAP respectively compared to control (Table 3a-b). However it was observed that $T_{3}-(200 \mathrm{~g}$ concentration) enhanced Leaf area more in table $3 b$ than in table $3 a$. However, the highest Leaf area was consistently obtained when $T_{3}(200 \mathrm{~g})$ of water extract was applied compared to ethanol extract as shown table $3 \mathrm{a}-\mathrm{b}$.

\section{Effect of Treatment on Leaf Area Index (LAI)}

Result from table 4a-b showed that turmeric extract from both extraction media had no significant effect on Leaf area index of plants. However, it was observed that it enhanced the Leaf area index of plant compared to control in both table $4 \mathrm{a}$ and $\mathrm{b}$. at 2, 4, 6, 8, 10 and 12 WAP turmeric starts from ethanol influence Leaf area index compared to control. The $\mathrm{T}_{3}$ gave the highest Leaf area index as shown in table $4 \mathrm{a}$. it was observed that $\mathrm{T}_{4}(300 \mathrm{~g})$ gave the lowest value of Leaf area index at 4, 6, 8, 10 and 12 WAP sampling periods.

In table $4 \mathrm{~b}$, at 4, 6, 8 and $10 \mathrm{WAP}$, turmeric extract of water application enhanced the Leaf area index. It was observed that increase concentration increases the Leaf area index with exception of $\mathrm{T}_{4}(300 \mathrm{~g})$ which recorded lower Leaf area index at $6 \mathrm{WAP}, 8,10$ and 12 WAP respectively.

\section{Effect of Treatment on Stem Girth (cm)}

The mean stem girth of okra plant grown in treated plots with turmeric ethanol extract was influenced by various treatment levels at sampling periods.

In table 5a, At 2, 6, 8, 10 and 12 WAP control plots consistently gave the highest number of stem girth $(0.71,5.63,11.20,10.57$ and $11.42 \mathrm{~cm}$ respectively) compare to treated plots as shown in table $5 \mathrm{a}$.

Similarly in table $5 \mathrm{~b}$, the same trend was observed at $6,8,10$ WAP for control plots compared to treated plots in turmeric water extracts application.

It was observed that in spite of control performance of stem girth was influenced more in turmeric water extract than in turmeric ethanol water extract (Table 5a and b)

\section{Effect of Treatment on Root Length $(\mathrm{cm})$}

In table 6a the trend in plots treated with turmeric ethanol extract as indicated influenced the root length at all the sampling stages compared to the control. It was observed that treated 3 recorded the highest root lengths $18.50 \mathrm{~cm}, 18.33 \mathrm{~cm}, 21.33 \mathrm{~cm}$ and $30.33 \mathrm{~cm}$ respectively at $4,6,8,10$ and 12 WAP compared to untreated plots. whereas the similar trend was observed in table5b. It was observed that $\mathrm{T}_{4}$ plots in turmeric water extract enhanced root length compared to $\mathrm{T}_{4}$ plots in turmeric ethanol extracts.

Comparatively turmeric water extract influenced root length more than turmeric ethanol extract as shown in table $6 a-b$

\section{Effect of Treatment on Root Dry Weight}

The result in table $7 \mathrm{a}$, shows that at 2, 6, 8, 10 and $12 \mathrm{WAP}$, the main root dry weight was highest (1.43g, 2.31, 17 and $26.42 \mathrm{~g}$ respectively) in plot that received $200 \mathrm{~g}\left(\mathrm{~T}_{3}\right)$ concentration compared to the lowest main root dry weight $(0.52,2.42,7.00,6.91$ and $10.00 \mathrm{~g}$ respectively) recorded from untreated plots (control)

\section{Effect of Treatment on Shoot Dry Weight}

Exogenous application of aqueous and ethanol turmeric extract enhanced the shoot dry weight of okra plant as shown in table 8a-b. in ethanol turmeric extract, application (table 8a), it was observed that, 
at 2, 4, 6, 8, 10 and 12 WAP there was no significant different in the main shoot dry weight recorded from treated plots compared to the control. $\mathrm{T}_{3}$ plots was observed to record higher shoot weights (31.91, 34.07 and 39.39 respectively) at 8,10 and $12 \mathrm{WAP}$ as indicated in table $8 \mathrm{a}$ compared to $\mathrm{T}_{1}, \mathrm{~T}_{2}$ and $\mathrm{T}_{4}$.

In table $8 \mathrm{~b}$, at 2, 4 and 6 WAP (That is early growth stage control recorded good performance compared to the treated plots although the observed difference was not significant whereas at 8,10 and $12 \mathrm{WAP}, \mathrm{T}_{3}$ plots recorded an enhanced main shoot dry weights compared to control, $\mathrm{T}_{2}$ and $\mathrm{T}_{4}$ treated plots.

In addition at later stage comparatively, aqueous turmeric extract enhanced shoot dry weight compared to the ethanol turmeric extract as indicated in table 8a-b

\section{Effect of Treatment on Proximate Composition}

Application of turmeric extract was observed to significantly $(\mathrm{p}<0.05)$ influenced proximate parameters as indicated in $9 \mathrm{a}$ and $\mathrm{b}$.

\section{Moisture Content}

In ethanol turmeric extract (table 9a), moisture content was found to be higher ( $85.81 \%$ which was significantly different $(\mathrm{P}<0.05)$ compared to values recorded from $\mathrm{T}_{2}(48.91 \%), \mathrm{T}_{3}(64.51 \%)$ and $\mathrm{T}_{4}$ $(61.21 \%)$

\section{Protein Content}

Protein content was highest $(2.34 \%)$ in plot treated with $\mathrm{T}_{3}(200 \mathrm{~g}$ concentration) of ethanol turmeric extract which was significantly different from the protein content recorded from $T_{2}(2.02), T_{1}(1.70)$ and $\mathrm{T}_{4}(1.60)$. whereas in aqueous $\mathrm{T}_{3}$ significantly $(\mathrm{p}<0.05)$ influenced the protein content with highest value of 2.41 compared to lower values $1.54,1.61$ and 1.68 recorded from $\mathrm{T}_{2}, \mathrm{~T}_{4}$ and $\mathrm{T}_{1}$ respectively.

\section{Vitamin C}

The control was found to have a higher number of vitamin $C$ relative to $T_{2}, T_{3}$ and $T_{4}$. The quantity of vitamin $C$ (21.10) recorded from control plots was significantly higher from the values $14.20,10.60$ and 12.71, recorded from $T_{2}, T_{3}$ and $T_{4}$ respectively. In table $9 b$, the same trend $\left(T_{1}>T_{2}>T_{4}>T_{3}\right)$ was observed in aqueous turmeric extract application.

\section{Calcium Content}

Plots treated with $\mathrm{T}_{2}$ ethanol turmeric extract contained (54.40) higher amount of calcium which was significantly $(\mathrm{P}<0.05)$ lower than 40.71 and 40.10 recorded from $\mathrm{T}_{1}$ and $\mathrm{T}_{3}$ plots respectively. Similarly, the same trend was observed in aqueous turmeric extract application.

\section{Fibre Content}

The fibre content was found to be significantly influenced by ethanol turmeric extract. $T_{3}$ plots recorded the highest fibre content (3.12) which was significantly difference $(\mathrm{P}<0.05)$ from the fibre content 2.32, 2.06 and 2.05 respectively recorded from plots treated with $\mathrm{T}_{1}, \mathrm{~T}_{2}$ and $\mathrm{T}_{4}$. Similarly in aqueous turmeric extract (Table 9b) $\mathrm{T}_{3}$ plots recorded higher fibre content (3.25) which was significantly different $(\mathrm{P}<0.05)$ from fibre content $\left(2.28,2.98\right.$ and 3.21 respectively) recorded from $\mathrm{T}_{1}$, $\mathrm{T}_{2}$ and $\mathrm{T}_{3}$.

\section{Ash Content}

Maximum Ash content (3.52) were noted from $\mathrm{T}_{3}$ treated plants which was significantly difference to Ash content $\left(2.80,3.00\right.$ and 3.30 respectively) recorded from $\mathrm{T}_{2}, \mathrm{~T}_{4}$ and $\mathrm{T}_{1}$ table $9 \mathrm{a}$. similarly Ash content obtained from $\mathrm{T}_{3}$ plant treated with aqueous turmeric extract recorded highest ash content (3.66) which was significantly different from Ash content (2.89, 2.90 and 3.32 respectively) recorded from $\mathrm{T}_{4}, \mathrm{~T}_{2}$ and $\mathrm{T}_{1}$ as indicated in table $9 \mathrm{~b}$.

\section{Carbohydrate}

In ethanol turmeric extract application (table 9a) maximum carbohydrate content (5.67) were obtained from control which was significantly different $(\mathrm{P}<0.05)$ from the lower carbohydrate content $(2.61$, 3.72 and 4.67 respectively recorded from $\mathrm{T}_{3}, \mathrm{~T}_{2}$ and $\mathrm{T}_{4}$ as indicated in table $9 \mathrm{a}$. 
Whereas in aqueous turmeric extract (table $9 \mathrm{~b}$ ) the same trend was observed where control recorded highest carbohydrate content which was significantly different $(\mathrm{P}<0.05)$ from the carbohydrate content $\left(3.75,4.34\right.$ and 5.12 respectively recorded from $\mathrm{T}_{4}, \mathrm{~T}_{3}$ and $\mathrm{T}_{2}$ as shown in table $\left.9 \mathrm{~b}\right)$

\section{Fat Content}

In table 9a, different levels of ethanol turmeric extract significantly influenced the fat content. $\mathrm{T}_{2}$ with fat content of $0.15, \mathrm{~T}_{4}(0.13)$ and $\mathrm{T}_{3}(0.12)$ all shows significant different $(\mathrm{P}<0.05)$ from lower value (0.10) obtained from control

In aqueous turmeric extract ( Table.9b), $\mathrm{T}_{2}$ plots recorded higher fat content $(0.55)$ which was significantly different, the lowest value $(0.08)$ recorded from control while $\mathrm{T}_{3}$ and $\mathrm{T}_{4}$ have the same values of fat content $(0.10)$ was significant to control.

\section{Effect of Treatment on Yield Components}

In table 10a, influenced of ethanol turmeric extract was not significant on the mean number of fruits although it increased the number of fruit when compared to control. $\mathrm{T}_{3}$ plots recorded a higher mean number of fruits (42), than the lower mean number fruits (23.33) recorded from control. Also, $\mathrm{T}_{2}$ and $\mathrm{T}_{4}$ recorded mean number of fruits (36.33 and 40.33), which are not significant to the mean number (23.33) of control plots (table 10a)

Similarly, the same trend was recorded in aqueous turmeric extract application, $T_{3}>T_{4}>T_{2}>T_{1}$. These observable difference statistically was not significant $(\mathrm{P}<0.05)$

\section{Mean Fresh Fruit Weight}

Application of turmeric extract have profound influence on the mean fresh weight of fruit relative control. In ethanol turmeric extract application (table 10a) it was observed that $\mathrm{T}_{3}$ plots recorded maximum mean fresh weight $(1055.00 \mathrm{~g})$ which was not significantly different $(\mathrm{P}<0.05)$ from the lowest $(543.30 \mathrm{~g})$ recorded from control.

Other treatment levels, $\mathrm{T}_{2}$ and $\mathrm{T}_{4}$ were found to have mean fresh weights $(889.0 \mathrm{~g}$ and $786.70 \mathrm{~g})$ which are higher than fresh weight $(543.30 \mathrm{~g})$ recorded from control.

Similarly, in aqueous turmeric extract (table 10b) it was observed that $\mathrm{T}_{3}$ recorded the highest mean fresh weight of $940.80 \mathrm{~g}$ which was not statistically significant to lower fresh weight $(542.90 \mathrm{~g})$ recorded from control.

It will be noted that $2 \%$ of ethanol turmeric extract have the highest mean fresh weight compared to $2 \%$ of aqueous turmeric extract.

\section{Yield (kg/ha)}

Application of turmeric extract from the two extract significantly improved the yield of Okra plants as indicated in table (10a-b).

In ethanol turmeric extract application (10a), the maximum yield (390.733kg/ha) was recorded from plots that received treatment $3(2 \%)$ which was significantly different $(\mathrm{P}<0.05)$ from yields $\left(84.10 / \mathrm{kg} / \mathrm{ha}, 362.60 \mathrm{~kg} / \mathrm{ha}\right.$ and $302.467 \mathrm{~kg} / \mathrm{ha}$ respectively) recorded from control, treatment ${ }_{2}$ and treatment ${ }_{4}$ respectively.

In table $10 \mathrm{~b}$, aqueous turmeric extract significantly influenced the yield of Okra plant. Among the treatment levels $\mathrm{T}_{3}(2 \%$ concentration) plots recorded higher $(385.600 \mathrm{~kg} / \mathrm{ha})$ yield which was significantly different $(\mathrm{P}<0.05)$ from the yields $(78.733 \mathrm{~kg} / \mathrm{ha}, 214.666 \mathrm{~kg} / \mathrm{ha}$ and $348.433 \mathrm{~kg} / \mathrm{ha}$ respectively) recorded from control $(0 \%), \mathrm{T}_{1}(1 \%)$ and $\mathrm{T}_{4}(3 \%)$ plots.

\section{DISCUSSION}

It is evident from this study that application of turmeric extract influenced the performance of Okra plant. However, degree of response depends on the concentration level and extract used.

Plant height was observed to be enhanced by treatment ${ }_{3}$ (2\% concentration) compared to control and other treatment levels in both extract used. The higher performance of Okra plants that received turmeric extract could be attributed to chemical content of turmeric extract (pigments, antioxidant and nutrients which might encourage cell division and biosynthesis of organic food. This is in conformity with work of Noric et al. 2002, and Ahmed et al. 2013. 
Ethanol and aqueous extract of turmeric was found to enhance the performance of Leaf area index, leaf area, number of root, root length compared to the plants from control plots. This enhancement could be that turmeric extract contents some growth enhancement substances, which impact more on these growth parameters than other parameters (stem girth and number of leaves). The increase in growth parameters may be due to the presence of some growth regulatory substances. Variation in the growth performance obtained might have been due to action of biochemical content in both aqueous extract and ethanol turmeric extract. This agreed with work of Ahmed et al., 2013 who reported that combined and single application of extract of Roselle turmeric and seaweed at $0.2 \%, 0.1 \%$ and $0.2 \%$ effectively improved the Leaf area, nutrients ( $\mathrm{N}, \mathrm{P}, \mathrm{K}$ and $\mathrm{Mg}$, total chlorophyll and total carotenoids in leaves, yield quality of Valencia orange trees).

The root dry weight and shoot dry weight were food to be improved by application of aqueous and ethanol turmeric extract although not statistically different it could be attributed to improvement in Leaf area which increase interception of light for fixation of carbon in the matrix of the plant during biosynthesis. The highest mean root dry weight and shoot dry weight were concomitant with using the higher level of turmeric extract ( $T_{3}$ especially) which improved the growth parameters than other treatment levels. Such increment might be due to that turmeric extract is a biostimulant, which provide Okra with micro and macro nutrients which increase the chlorophyll production by boosting the photosynthesis process, thereby stimulating vegetative growth. This agreed with work of some authors (Parohit, 2000; Okigbo and emoghene, 2003, Chawdhury et al. 2007; Bhdwaji et al. 2010; Abd El-Rahman and El-Masry, 2012; Ahmed et al. 2013 and Mohammed and Mohammed, 2013) who found that plant extracts enhance growth, nutritional status, yield and fruit quality of fruit crops.

Nutritional status was found to be significantly improved by turmeric extract. It was observed that, $2 \%$ level impacted positively on protein content, fibre, fat, calcium content of Okra plant relative to moisture content, vitamin $\mathrm{C}$ content and carbohydrate. The improvement on the nutritional content could be due to nutrient content of turmeric extract such as $\mathrm{N}$., $\mathrm{P}, \mathrm{K}, \mathrm{Ca}$ and $\mathrm{Mg}$ and vitamins, which protect DNA damage in the plant. These results are in harmony with those obtained by Chawdhury et al. 2007, Karim and Rahim 2008, Ahmed et al. 2014.

Yield could be considered to be the mirror of all growth features. Comparing the effect of different levels of spraying treatments on yield and yield component, the results indicate that, in spite of no significant difference were detected among control treatment and aqueous, and ethanol extract, on number of fruits and fresh weight, it was clear that turmeric extract (both ethanol and aqueous) at 2\% tested concentration significantly increased yield compared to those of untreated plots. These increase in the number of fruits, fresh weights and significant increase in the yield could be attributed to the presence of nutrients (such as calcium, phosphorus, potassium and magnesium) Vitamins, some growth regulators in turmeric extract. The use of such materials on Okra plant will improve the physiological and nutritional statues of the Okra plants and increase the yield and fruit quality. This is in harmony with Ahmed et al. (2013 and Hageb et al., 2005) on citrus, Hafez et al. (2013) on Olive, and Hanafy, et al. (2012) on plant extract.

\section{CONCLUSION}

From the above results it could be concluded that using turmeric extract (both ethanol and aqueous extract) at T3 (2\% concentration) had clear effects on vegetative growth, nutritional status, yield and yield components.

It was noted that aqueous turmeric extract have greater impact on the growth parameters measured compared to ethanol turmeric extract. Therefore, within the limit of this study, $2 \%$ extract concentration $\left(T_{3}\right)$ of both extract could be safely recommended as natural bio stimulant application for improving fruiting of okra plants.

Table 1. Effect of Treatment on Plant Height $(\mathrm{cm})$

Table 1a. (Ethanol Turmeric Extract)

\begin{tabular}{|l|l|l|l|l|l|l|}
\hline Treatments & 2 WAP & 4 WAP & 6 WAP & 8 WAP & 10 WAP & 12 WAP \\
\hline $\mathrm{T}_{1}$ & $5.93^{\mathrm{a}}$ & $7.90^{\mathrm{a}}$ & $15.50^{\mathrm{a}}$ & $27.17^{\mathrm{b}}$ & $36.33^{\mathrm{b}}$ & $50.87^{\mathrm{b}}$ \\
\hline $\mathrm{T}_{2}$ & $6.50^{\mathrm{a}}$ & $10.83^{\mathrm{a}}$ & $15.33^{\mathrm{a}}$ & $31.83^{\mathrm{ab}}$ & $45.00^{\mathrm{ab}}$ & $62.63^{\mathrm{ab}}$ \\
\hline $\mathrm{T}_{3}$ & $6.33^{\mathrm{a}}$ & $10.83^{\mathrm{a}}$ & $22.53^{\mathrm{a}}$ & $45.50^{\mathrm{a}}$ & $62.00^{\mathrm{a}}$ & $84.50^{\mathrm{a}}$ \\
\hline $\mathrm{T}_{4}$ & $5.50^{\mathrm{a}}$ & $9.73^{\mathrm{a}}$ & $18.83^{\mathrm{a}}$ & $34.17^{\mathrm{ab}}$ & $48.33^{\mathrm{ab}}$ & $71.00^{\mathrm{ab}}$ \\
\hline L.S.D & 2.20 & 4.31 & 8.54 & 14.26 & 19.20 & 24.32 \\
\hline
\end{tabular}


OGBUEHI, H.C et al.

Table 1b. (Aqueous Turmeric Extract)

\begin{tabular}{|l|l|l|l|l|l|l|}
\hline Treatments & 2 WAP & 4 WAP & 6 WAP & 8 WAP & 10 WAP & 12 WAP \\
\hline $\mathrm{T}_{1}$ & $6.07^{\mathrm{a}}$ & $7.53^{\mathrm{a}}$ & $15.77^{\mathrm{a}}$ & $27.23^{\mathrm{b}}$ & $37.67^{\mathrm{b}}$ & $57.00^{\mathrm{b}}$ \\
\hline $\mathrm{T}_{2}$ & $5.50^{\mathrm{a}}$ & $9.00^{\mathrm{a}}$ & $17.00^{\mathrm{a}}$ & $27.50^{\mathrm{b}}$ & $40.17^{\mathrm{b}}$ & $61.23^{\mathrm{ab}}$ \\
\hline $\mathrm{T}_{3}$ & $5.17^{\mathrm{a}}$ & $9367^{\mathrm{a}}$ & $20.50^{\mathrm{a}}$ & $43.00^{\mathrm{a}}$ & $65.00^{\mathrm{a}}$ & $85.17^{\mathrm{a}}$ \\
\hline $\mathrm{T}_{4}$ & $4.73^{\mathrm{a}}$ & $8.83^{\mathrm{a}}$ & $16.17^{\mathrm{a}}$ & $30.00^{\mathrm{ab}}$ & $41.00^{\mathrm{ab}}$ & $65.00^{\mathrm{ab}}$ \\
\hline L.S.D & 3.36 & 4.00 & 8.57 & 15.00 & 24.22 & 24.25 \\
\hline
\end{tabular}

Means in the same column, having the same letter according to LSD are not significant $(\mathrm{P}<0.05)$.

Table 2. Effect of Treatments on Number of Leaves

Table 2a. (Ethanol Turmeric Extract)

\begin{tabular}{|l|l|l|l|l|l|l|}
\hline Treatments & $\mathbf{2} \mathbf{W A P}$ & $\mathbf{4} \mathbf{W A P}$ & $\mathbf{6 ~ W A P}$ & $\mathbf{8 ~ W A P}$ & $\mathbf{1 0} \mathbf{W A P}$ & 12 WAP \\
\hline $\mathrm{T}_{1}$ & $5.00^{\mathrm{a}}$ & $8.00^{\mathrm{b}}$ & $10.33^{\mathrm{a}}$ & $16.00^{\mathrm{a}}$ & $37.00^{\mathrm{a}}$ & $52.33^{\mathrm{a}}$ \\
\hline $\mathrm{T}_{2}$ & $4.33^{\mathrm{a}}$ & $9.67^{\mathrm{a}}$ & $16.00^{\mathrm{a}}$ & $19.00^{\mathrm{a}}$ & $26.67^{\mathrm{a}}$ & $47.67^{\mathrm{a}}$ \\
\hline $\mathrm{T}_{3}$ & $5.67^{\mathrm{a}}$ & $9.67^{\mathrm{a}}$ & $12.00^{\mathrm{ab}}$ & $18.33^{\mathrm{a}}$ & $31.33^{\mathrm{a}}$ & $36.67^{\mathrm{a}}$ \\
\hline $\mathrm{T}_{4}$ & $5.00^{\mathrm{a}}$ & $8.33^{\mathrm{ab}}$ & $9.67^{\mathrm{a}}$ & $14.67^{\mathrm{a}}$ & $24.67^{\mathrm{a}}$ & $35.67^{\mathrm{a}}$ \\
\hline L.S.D & 1.40 & 1.40 & 5.12 & 13.40 & 24.71 & 32.04 \\
\hline
\end{tabular}

Table 2b. (Aqueous Turmeric Extract)

\begin{tabular}{|l|l|l|l|l|l|l|}
\hline Treatments & $\mathbf{2} \mathbf{W A P}$ & $\mathbf{4} \mathbf{W A P}$ & $\mathbf{6 ~ W A P}$ & $\mathbf{8 ~ W A P}$ & $\mathbf{1 0} \mathbf{W A P}$ & $\mathbf{1 2}$ WAP \\
\hline $\mathrm{T}_{1}$ & $4.67^{\mathrm{a}}$ & $8.33^{\mathrm{a}}$ & $10.67^{\mathrm{a}}$ & $16.00^{\mathrm{a}}$ & $37.67^{\mathrm{a}}$ & $46.33^{\mathrm{a}}$ \\
\hline $\mathrm{T}_{2}$ & $5.00^{\mathrm{a}}$ & $8.00^{\mathrm{a}}$ & $10.33^{\mathrm{a}}$ & $16.00^{\mathrm{a}}$ & $25.00^{\mathrm{a}}$ & $39.33^{\mathrm{a}}$ \\
\hline $\mathrm{T}_{3}$ & $5.33^{\mathrm{a}}$ & $9.00^{\mathrm{a}}$ & $10.67^{\mathrm{a}}$ & $19.00^{\mathrm{a}}$ & $26.67^{\mathrm{a}}$ & $46.00^{\mathrm{a}}$ \\
\hline $\mathrm{T}_{4}$ & $5.00^{\mathrm{a}}$ & $8.33^{\mathrm{a}}$ & $10.00^{\mathrm{a}}$ & $19.00^{\mathrm{a}}$ & $29.67^{\mathrm{a}}$ & $42.67^{\mathrm{a}}$ \\
\hline L.S.D & 1.10 & 1.66 & 4.04 & 16.44 & 37.80 & 35.80 \\
\hline
\end{tabular}

Means in the same column, having the same letter according to LSD are not significant $(\mathrm{P}<0.05)$.

Table 3. Effect of Treatments on Leaf Area $\left(\mathrm{cm}^{2}\right)$

Table 3a. (Ethanol Turmeric Extract)

\begin{tabular}{|l|l|l|l|l|l|l|}
\hline Treatments & $\mathbf{2}$ WAP & 4 WAP & 6 WAP & 8 WAP & 10 WAP & 12 WAP \\
\hline $\mathrm{T}_{1}$ & $27.10^{\mathrm{a}}$ & $121.17^{\mathrm{a}}$ & $282.67^{\mathrm{a}}$ & $336.58^{\mathrm{a}}$ & $413.92^{\mathrm{a}}$ & $402.00^{\mathrm{a}}$ \\
\hline $\mathrm{T}_{2}$ & $23.00^{\mathrm{a}}$ & $131.73^{\mathrm{a}}$ & $239.68^{\mathrm{ab}}$ & $404.17^{\mathrm{a}}$ & $427.17^{\mathrm{a}}$ & $440.58^{\mathrm{a}}$ \\
\hline $\mathrm{T}_{3}$ & $22.00^{\mathrm{a}}$ & $130.42^{\mathrm{a}}$ & $190.38 \mathrm{~b}^{\mathrm{c}}$ & $383.08^{\mathrm{a}}$ & $423.33^{\mathrm{a}}$ & $434.83^{\mathrm{a}}$ \\
\hline $\mathrm{T}_{4}$ & $18.00^{\mathrm{a}}$ & $92.68^{\mathrm{a}}$ & $154.00^{\mathrm{c}}$ & $294.98^{\mathrm{a}}$ & $317.92^{\mathrm{a}}$ & $383.08^{\mathrm{a}}$ \\
\hline L.S.D & 16.00 & 70.00 & 54.78 & 135.71 & 120.71 & 102.48 \\
\hline
\end{tabular}

Table 3b. (Aqueous Turmeric Extract)

\begin{tabular}{|l|l|l|l|l|l|l|}
\hline Treatments & $\mathbf{2} \mathbf{W A P}$ & $\mathbf{4} \mathbf{W A P}$ & $\mathbf{6 ~ W A P}$ & $\mathbf{8 ~ W A P}$ & $\mathbf{1 0 ~ W A P}$ & 12 WAP \\
\hline $\mathrm{T}_{1}$ & $27.07^{\mathrm{a}}$ & $124.37^{\mathrm{a}}$ & $282.97^{\mathrm{a}}$ & $356.58^{\mathrm{a}}$ & $412.48^{\mathrm{a}}$ & $402.58^{\mathrm{a}}$ \\
\hline $\mathrm{T}_{2}$ & $23.41^{\mathrm{a}}$ & $110.00^{\mathrm{a}}$ & $226.00^{\mathrm{a}}$ & $311.00^{\mathrm{a}}$ & $342.83^{\mathrm{a}}$ & $442.58^{\mathrm{a}}$ \\
\hline $\mathrm{T}_{3}$ & $27.55^{\mathrm{a}}$ & $103.92^{\mathrm{a}}$ & $201.58^{\mathrm{a}}$ & $380.00^{\mathrm{a}}$ & $418.33^{\mathrm{a}}$ & $469.33^{\mathrm{a}}$ \\
\hline $\mathrm{T}_{4}$ & $23.22^{\mathrm{a}}$ & $83.58^{\mathrm{a}}$ & $224.50^{\mathrm{a}}$ & $351.25^{\mathrm{a}}$ & $389.58^{\mathrm{a}}$ & $442.50^{\mathrm{a}}$ \\
\hline L.S.D & 8.50 & 100.31 & 145.05 & 149.04 & 152.54 & 193.81 \\
\hline
\end{tabular}

Means in the same column, having the same letter according to LSD are not significant $(\mathrm{P}<0.05)$.

Table 4. Effect of Treatments on Leaf Area Index

Table 4a. (Ethanol Turmeric Extract)

\begin{tabular}{|l|l|l|l|l|l|l|}
\hline Treatments & 2 WAP & 4 WAP & 6 WAP & 8 WAP & 10 WAP & 12 WAP \\
\hline $\mathrm{T}_{1}$ & $5.43^{\mathrm{b}}$ & $9.20^{\mathrm{a}}$ & $23.00^{\mathrm{a}}$ & $35.00^{\mathrm{a}}$ & $36.00^{\mathrm{a}}$ & $44.00^{\mathrm{a}}$ \\
\hline $\mathrm{T}_{2}$ & $7.33^{\mathrm{a}}$ & $8.50^{\mathrm{a}}$ & $24.00^{\mathrm{a}}$ & $41.00^{\mathrm{a}}$ & $39.00^{\mathrm{a}}$ & $46.00^{\mathrm{a}}$ \\
\hline $\mathrm{T}_{3}$ & $6.10^{\mathrm{ab}}$ & $14.00^{\mathrm{a}}$ & $28.00^{\mathrm{a}}$ & $36.00^{\mathrm{a}}$ & $37.00^{\mathrm{a}}$ & $46.20^{\mathrm{a}}$ \\
\hline $\mathrm{T}_{4}$ & $6.30^{\mathrm{ab}}$ & $15.00^{\mathrm{a}}$ & $23.03^{\mathrm{a}}$ & $35.50^{\mathrm{a}}$ & $34.00^{\mathrm{a}}$ & $41.00^{\mathrm{a}}$ \\
\hline L.S.D & 1.71 & 6.24 & 15.00 & 10.22 & 13.00 & 17.00 \\
\hline
\end{tabular}

Table 4b. (Aqueous Turmeric Extract)

\begin{tabular}{|l|l|l|l|l|l|l|}
\hline Treatments & 2 WAP & 4 WAP & 6 WAP & 8 WAP & 10 WAP & 12 WAP \\
\hline $\mathrm{T}_{1}$ & $5.40^{\mathrm{a}}$ & $9.07^{\mathrm{a}}$ & $22.57^{\mathrm{a}}$ & $33.73^{\mathrm{a}}$ & $36.33^{\mathrm{a}}$ & $41.67^{\mathrm{a}}$ \\
\hline $\mathrm{T}_{2}$ & $5.63^{\mathrm{a}}$ & $13.00^{\mathrm{a}}$ & $20.17^{\mathrm{a}}$ & $33.67^{\mathrm{a}}$ & $35.33^{\mathrm{a}}$ & $39.67^{\mathrm{a}}$ \\
\hline $\mathrm{T}_{3}$ & $6.23^{\mathrm{a}}$ & $8.83^{\mathrm{a}}$ & $28.57^{\mathrm{a}}$ & $35.00^{\mathrm{a}}$ & $38.00^{\mathrm{a}}$ & $48.00^{\mathrm{a}}$ \\
\hline
\end{tabular}


Growth, Fruiting, Yield and Nutritional Content of Okra Plant (Abelmoschus Esculentus (L.) Moench) as Influenced by Turmeric (Curcuma Longa) Extracts Spray

\begin{tabular}{|l|l|l|l|l|l|l|}
\hline \hline $\mathrm{T}_{4}$ & $4.83^{\mathrm{a}}$ & $11.00^{\mathrm{a}}$ & $25.00^{\mathrm{a}}$ & $34.67^{\mathrm{a}}$ & $36.00^{\mathrm{a}}$ & $43.00^{\mathrm{a}}$ \\
\hline L.S.D & 2.01 & 7.77 & 15.00 & 14.30 & 11.93 & 17.73 \\
\hline
\end{tabular}

Means in the same column, having the same letter according to LSD are not significant $(\mathrm{P}<0.05)$.

Table 5. Effect of Treatments on Stem Girth $(\mathrm{cm})$

Table 5a. (Ethanol Turmeric Extract)

\begin{tabular}{|l|l|l|l|l|l|l|}
\hline Treatments & $\mathbf{2 ~ W A P}$ & 4 WAP & 6 WAP & $\mathbf{8 ~ W A P}$ & $\mathbf{1 0 ~ W A P}$ & 12 WAP \\
\hline $\mathrm{T}_{1}$ & $0.71^{\mathrm{a}}$ & $3.22^{\mathrm{a}}$ & $5.63^{\mathrm{a}}$ & $11.20^{\mathrm{a}}$ & $10.57^{\mathrm{a}}$ & $11.42^{\mathrm{a}}$ \\
\hline $\mathrm{T}_{2}$ & $0.83^{\mathrm{a}}$ & $3.65^{\mathrm{a}}$ & $5.88^{\mathrm{a}}$ & $8.92^{\mathrm{a}}$ & $6.28^{\mathrm{a}}$ & $7.00^{\mathrm{a}}$ \\
\hline $\mathrm{T}_{3}$ & $0.42^{\mathrm{a}}$ & $3.50^{\mathrm{a}}$ & $5.35^{\mathrm{a}}$ & $6.07^{\mathrm{a}}$ & $8.83^{\mathrm{a}}$ & $9.08^{\mathrm{a}}$ \\
\hline $\mathrm{T}_{4}$ & $0.50^{\mathrm{a}}$ & $3.43^{\mathrm{a}}$ & $4.17^{\mathrm{a}}$ & $8.03^{\mathrm{a}}$ & $5.25^{\mathrm{a}}$ & $5.53^{\mathrm{a}}$ \\
\hline L.S.D & 0.37 & 0.95 & 1.43 & 3.00 & 3.30 & 3.34 \\
\hline
\end{tabular}

Table 5b. (Aqueous Turmeric Extract)

\begin{tabular}{|l|l|l|l|l|l|l|}
\hline Treatments & $\mathbf{2}$ WAP & 4 WAP & 6 WAP & 8 WAP & 10 WAP & 12 WAP \\
\hline $\mathrm{T}_{1}$ & $0.68^{\mathrm{a}}$ & $3.40^{\mathrm{a}}$ & $7.53^{\mathrm{a}}$ & $10.50^{\mathrm{a}}$ & $12.27^{\mathrm{a}}$ & $11.35^{\mathrm{a}}$ \\
\hline $\mathrm{T}_{2}$ & $1.40^{\mathrm{a}}$ & $5.12^{\mathrm{a}}$ & $6.21^{\mathrm{a}}$ & $10.67^{\mathrm{a}}$ & $8.00^{\mathrm{a}}$ & $12.00^{\mathrm{a}}$ \\
\hline $\mathrm{T}_{3}$ & $1.63^{\mathrm{a}}$ & $4.34^{\mathrm{a}}$ & $6.51^{\mathrm{a}}$ & $10.33^{\mathrm{a}}$ & $9.67^{\mathrm{a}}$ & $16.00^{\mathrm{a}}$ \\
\hline $\mathrm{T}_{4}$ & $1.52^{\mathrm{a}}$ & $3.75^{\mathrm{a}}$ & $6.42^{\mathrm{a}}$ & $10.00^{\mathrm{a}}$ & $8.33^{\mathrm{a}}$ & $10.33^{\mathrm{a}}$ \\
\hline L.S.D & 0.72 & 1.10 & 1.66 & 4.00 & 5.12 & 8.54 \\
\hline
\end{tabular}

Means in the same column, having the same letter according to LSD are not significant $(\mathrm{P}<0.05)$.

Table 6. Effect of Treatments on Root Length $(\mathrm{cm})$

Table 6a. (Ethanol Turmeric Extract)

\begin{tabular}{|l|l|l|l|l|l|l|}
\hline Treatments & 2 WAP & 4 WAP & 6 WAP & 8 WAP & 10 WAP & 12 WAP \\
\hline $\mathrm{T}_{1}$ & $4.64^{\mathrm{a}}$ & $18.33^{\mathrm{a}}$ & $18.33^{\mathrm{a}}$ & $14.83^{\mathrm{a}}$ & $16.33^{\mathrm{a}}$ & $23.33^{\mathrm{a}}$ \\
\hline $\mathrm{T}_{2}$ & $2.34^{\mathrm{a}}$ & $12.67^{\mathrm{b}}$ & $20.67^{\mathrm{a}}$ & $14.50^{\mathrm{a}}$ & $16.00^{\mathrm{a}}$ & $26.00^{\mathrm{a}}$ \\
\hline $\mathrm{T}_{3}$ & $3.08^{\mathrm{a}}$ & $16.67^{\mathrm{ab}}$ & $18.50^{\mathrm{a}}$ & $18.33^{\mathrm{a}}$ & $21.33^{\mathrm{a}}$ & $30.33^{\mathrm{a}}$ \\
\hline $\mathrm{T}_{4}$ & $3.36^{\mathrm{a}}$ & $16.33^{\mathrm{ab}}$ & $24.83^{\mathrm{a}}$ & $17.83^{\mathrm{a}}$ & $17.00^{\mathrm{a}}$ & $30.33^{\mathrm{a}}$ \\
\hline L.S.D & 2.45 & 5.26 & 11.00 & 9.70 & 12.10 & 11.80 \\
\hline
\end{tabular}

Table 6b. (Aqueous Turmeric Extract)

\begin{tabular}{|l|l|l|l|l|l|l|}
\hline Treatments & 2 WAP & 4 WAP & 6 WAP & 8 WAP & 10 WAP & 12 WAP \\
\hline $\mathrm{T}_{1}$ & $4.87^{\mathrm{a}}$ & $18.53^{\mathrm{a}}$ & $18.27^{\mathrm{ab}}$ & $14.83^{\mathrm{a}}$ & $16.67^{\mathrm{a}}$ & $27.00^{\mathrm{a}}$ \\
\hline $\mathrm{T}_{2}$ & $2.70^{\mathrm{b}}$ & $12.17^{\mathrm{b}}$ & $13.17^{\mathrm{b}}$ & $18.83^{\mathrm{a}}$ & $25.00^{\mathrm{a}}$ & $31.00^{\mathrm{a}}$ \\
\hline $\mathrm{T}_{3}$ & $2.96^{\mathrm{a}}$ & $14.33^{\mathrm{ab}}$ & $15.33^{\mathrm{b}}$ & $18.83^{\mathrm{a}}$ & $24.00^{\mathrm{a}}$ & $30.17^{\mathrm{a}}$ \\
\hline $\mathrm{T}_{4}$ & $5.71^{\mathrm{a}}$ & $13.50 \mathrm{a}^{\mathrm{b}}$ & $22.33^{\mathrm{a}}$ & $23.00^{\mathrm{a}}$ & $24.00^{\mathrm{a}}$ & $31.83^{\mathrm{a}}$ \\
\hline L.S.D & 2.35 & 5.70 & 6.45 & 11.00 & 13.29 & 13.83 \\
\hline
\end{tabular}

Means in the same column, having the same letter according to LSD are not significant $(\mathrm{P}<0.05)$.

Table 7. Effect of Treatments on Root Dry Weight

Table 7a. (Ethanol Turmeric Extract)

\begin{tabular}{|l|l|l|l|l|l|l|}
\hline Treatments & 2 WAP & 4 WAP & 6 WAP & 8 WAP & 10 WAP & 12 WAP \\
\hline $\mathrm{T}_{1}$ & $0.89^{\mathrm{a}}$ & $0.52^{\mathrm{b}}$ & $2.42^{\mathrm{a}}$ & $7.00^{\mathrm{a}}$ & $6.91^{\mathrm{a}}$ & $10.00^{\mathrm{a}}$ \\
\hline $\mathrm{T}_{2}$ & $0.32^{\mathrm{a}}$ & $0.54^{\mathrm{b}}$ & $3.71^{\mathrm{a}}$ & $10.27^{\mathrm{a}}$ & $8.20^{\mathrm{a}}$ & $13.32^{\mathrm{a}}$ \\
\hline $\mathrm{T}_{3}$ & $0.84^{\mathrm{a}}$ & $1.43^{\mathrm{a}}$ & $2.40^{\mathrm{a}}$ & $20.31^{\mathrm{a}}$ & $17.00^{\mathrm{a}}$ & $26.42^{\mathrm{a}}$ \\
\hline $\mathrm{T}_{4}$ & $0.68^{\mathrm{a}}$ & $1.21^{\mathrm{ab}}$ & $3.40^{\mathrm{a}}$ & $15.09^{\mathrm{a}}$ & $10.50^{\mathrm{a}}$ & $18.20^{\mathrm{a}}$ \\
\hline L.S.D & 0.35 & 0.80 & 3.10 & 28.03 & 15.10 & 20.00 \\
\hline
\end{tabular}

Table 7b. (Aqueous Turmeric Extract)

\begin{tabular}{|l|l|l|l|l|l|l|}
\hline Treatments & 2 WAP & 4 WAP & 6 WAP & 8 WAP & 10 WAP & 12 WAP \\
\hline $\mathrm{T}_{1}$ & $0.43^{\mathrm{b}}$ & $0.53^{\mathrm{a}}$ & $2.43^{\mathrm{a}}$ & $7.01^{\mathrm{a}}$ & $6.83^{\mathrm{a}}$ & $9.87^{\mathrm{b}}$ \\
\hline $\mathrm{T}_{2}$ & $0.80^{\mathrm{a}}$ & $1.31^{\mathrm{a}}$ & $1.86^{\mathrm{a}}$ & $17.93^{\mathrm{a}}$ & $14.75^{\mathrm{a}}$ & $21.90^{\mathrm{ab}}$ \\
\hline $\mathrm{T}_{3}$ & $0.29^{\mathrm{bc}}$ & $0.54^{\mathrm{a}}$ & $1.70^{\mathrm{a}}$ & $17.71^{\mathrm{a}}$ & $17.17^{\mathrm{a}}$ & $28.37^{\mathrm{a}}$ \\
\hline $\mathrm{T}_{4}$ & $0.40^{\mathrm{b}}$ & $0.75^{\mathrm{a}}$ & $3.77^{\mathrm{a}}$ & $13.20^{\mathrm{a}}$ & $14.43^{\mathrm{a}}$ & $22.23^{\mathrm{ab}}$ \\
\hline L.S.D & 0.31 & 1.27 & 3.26 & 17.77 & 13.41 & 17.54 \\
\hline
\end{tabular}

Means in the same column, having the same letter according to LSD are not significant $(\mathrm{P}<0.05)$. 
OGBUEHI, H.C et al.

Table 8. Effect of Treatments on Shoot Dry Weight

Table 8a. (Ethanol Turmeric Extract)

\begin{tabular}{|l|l|l|l|l|l|l|}
\hline Treatments & 2 WAP & 4 WAP & 6 WAP & 8 WAP & 10 WAP & 12 WAP \\
\hline $\mathrm{T}_{1}$ & $0.95^{\mathrm{a}}$ & $1.27^{\mathrm{a}}$ & $4.00^{\mathrm{a}}$ & $10.59^{\mathrm{a}}$ & $12.05^{\mathrm{a}}$ & $16.04^{\mathrm{a}}$ \\
\hline $\mathrm{T}_{2}$ & $0.67^{\mathrm{a}}$ & $1.11^{\mathrm{a}}$ & $6.10^{\mathrm{a}}$ & $15.67^{\mathrm{a}}$ & $16.57^{\mathrm{a}}$ & $19.74^{\mathrm{a}}$ \\
\hline $\mathrm{T}_{3}$ & $1.29^{\mathrm{a}}$ & $2.20^{\mathrm{a}}$ & $4.51^{\mathrm{a}}$ & $31.91^{\mathrm{a}}$ & $34.07^{\mathrm{a}}$ & $39.39^{\mathrm{a}}$ \\
\hline $\mathrm{T}_{4}$ & $1.13^{\mathrm{a}}$ & $2.00^{\mathrm{a}}$ & $5.51^{\mathrm{a}}$ & $20.99^{\mathrm{a}}$ & $21.80^{\mathrm{a}}$ & $25.27^{\mathrm{a}}$ \\
\hline L.S.D & 0.80 & 1.40 & 5.10 & 36.40 & 36.10 & 37.00 \\
\hline
\end{tabular}

Table 8b. (Aqueous Turmeric Extract)

\begin{tabular}{|l|l|l|l|l|l|l|}
\hline Treatments & $\mathbf{2}$ WAP & 4 WAP & 6 WAP & $\mathbf{8}$ WAP & 10 WAP & 12 WAP \\
\hline $\mathrm{T}_{1}$ & $1.06^{\mathrm{a}}$ & $1.01^{\mathrm{a}}$ & $3.80^{\mathrm{a}}$ & $10.56^{\mathrm{a}}$ & $12.08^{\mathrm{a}}$ & $15.87^{\mathrm{a}}$ \\
\hline $\mathrm{T}_{2}$ & $1.11^{\mathrm{a}}$ & $1.82^{\mathrm{a}}$ & $3.29^{\mathrm{a}}$ & $26.93^{\mathrm{a}}$ & $29.43^{\mathrm{a}}$ & $38.04^{\mathrm{a}}$ \\
\hline $\mathrm{T}_{3}$ & $0.54^{\mathrm{a}}$ & $1.01^{\mathrm{a}}$ & $2.59^{\mathrm{a}}$ & $27.58^{\mathrm{a}}$ & $31.12^{\mathrm{a}}$ & $40.74^{\mathrm{a}}$ \\
\hline $\mathrm{T}_{4}$ & $0.81^{\mathrm{a}}$ & $1.53^{\mathrm{a}}$ & $5.97^{\mathrm{a}}$ & $22.98^{\mathrm{a}}$ & $28.90^{\mathrm{a}}$ & $38.75^{\mathrm{a}}$ \\
\hline L.S.D & 0.56 & 1.23 & 5.03 & 26.65 & 24.42 & 25.74 \\
\hline
\end{tabular}

Means in the same column, having the same letter according to LSD are not significant $(\mathrm{P}<0.05)$.

TABLE 9. Effect of Treatments on Proximate Composition

Table 9a. (Ethanol Turmeric Extract)

\begin{tabular}{|l|l|l|l|l|l|l|l|l|}
\hline Treatments & M.C & Protein & Vit. C & Calcium & Fibre & Ash & Total fat & Carbohy-drate \\
\hline $\mathrm{T}_{1}$ & $85.81^{\mathrm{a}}$ & $1.70^{\mathrm{c}}$ & $21.10^{\mathrm{a}}$ & $40.71^{\mathrm{c}}$ & $2.32^{\mathrm{b}}$ & $3.30^{\mathrm{b}}$ & $0.10^{\mathrm{c}}$ & $5.67^{\mathrm{a}}$ \\
\hline $\mathrm{T}_{2}$ & $48.91^{\mathrm{d}}$ & $2.02^{\mathrm{b}}$ & $14.20^{\mathrm{b}}$ & $54.40^{\mathrm{a}}$ & $2.06^{\mathrm{c}}$ & $2.80^{\mathrm{d}}$ & $0.15^{\mathrm{a}}$ & $3.72^{\mathrm{c}}$ \\
\hline $\mathrm{T}_{3}$ & $64.51^{\mathrm{b}}$ & $2.34^{\mathrm{a}}$ & $10.60^{\mathrm{d}}$ & $40.10^{\mathrm{d}}$ & $3.12^{\mathrm{a}}$ & $3.52^{\mathrm{a}}$ & $0.12 \mathrm{~b}^{\mathrm{c}}$ & $2.61^{\mathrm{d}}$ \\
\hline $\mathrm{T}_{4}$ & $61.21^{\mathrm{c}}$ & $1.60^{\mathrm{d}}$ & $12.71^{\mathrm{c}}$ & $50.10^{\mathrm{b}}$ & $2.05^{\mathrm{c}}$ & $3.00^{\mathrm{c}}$ & $0.13 \mathrm{a}^{\mathrm{b}}$ & $4.67^{\mathrm{b}}$ \\
\hline L.S.D & 0.04 & 0.07 & 0.03 & 0.52 & 0.10 & 0.10 & 0.02 & 0.03 \\
\hline
\end{tabular}

Table 9b. (Aqueous Turmeric Extract)

\begin{tabular}{|l|l|l|l|l|l|l|l|l|}
\hline Treatments & M.C & Protein & Vit. C & Calcium & Fibre & Ash & Total fat & Carbohy-drate \\
\hline $\mathrm{T}_{1}$ & $85.85^{\mathrm{a}}$ & $1.68^{\mathrm{b}}$ & $21.05^{\mathrm{a}}$ & $41.23^{\mathrm{d}}$ & $2.28^{\mathrm{d}}$ & $3.32^{\mathrm{b}}$ & $0.08^{\mathrm{b}}$ & $5.64^{\mathrm{a}}$ \\
\hline $\mathrm{T}_{2}$ & $57.10^{\mathrm{d}}$ & $1.54^{\mathrm{d}}$ & $18.10^{\mathrm{b}}$ & $50.42^{\mathrm{a}}$ & $2.98^{\mathrm{c}}$ & $2.90^{\mathrm{c}}$ & $0.55^{\mathrm{a}}$ & $5.12^{\mathrm{b}}$ \\
\hline $\mathrm{T}_{3}$ & $78.02^{\mathrm{b}}$ & $2.41^{\mathrm{a}}$ & $13.04^{\mathrm{d}}$ & $42.50^{\mathrm{c}}$ & $3.66^{\mathrm{a}}$ & $3.66^{\mathrm{a}}$ & $0.10^{\mathrm{b}}$ & $4.34^{\mathrm{c}}$ \\
\hline $\mathrm{T}_{4}$ & $62.40^{\mathrm{c}}$ & $1.61^{\mathrm{c}}$ & $13.52^{\mathrm{c}}$ & $49.12^{\mathrm{b}}$ & $2.89^{\mathrm{c}}$ & $2.89^{\mathrm{c}}$ & $0.10^{\mathrm{b}}$ & $3.75^{\mathrm{d}}$ \\
\hline L.S.D & 0.05 & 0.02 & 0.05 & 0.14 & 0.02 & 0.03 & 0.10 & 0.03 \\
\hline
\end{tabular}

Means in the same column, having the same letter according to LSD are not significant $(\mathrm{P}<0.05)$.

Table 10. Effect of Treatments on Yield and Yield Components

Table 10a. (Ethanol Turmeric Extract)

\begin{tabular}{|l|l|l|l|}
\hline Treatments & Number of fruit & Mean fresh weight & Yield (kg/ha) \\
\hline $\mathrm{T}_{1}$ & $23.33^{\mathrm{a}}$ & $543.30^{\mathrm{a}}$ & $84.100^{\mathrm{a}}$ \\
\hline $\mathrm{T}_{2}$ & $36.33^{\mathrm{a}}$ & $889.00^{\mathrm{a}}$ & $362.600 \mathrm{a}^{\mathrm{b}}$ \\
\hline $\mathrm{T}_{3}$ & $42.00^{\mathrm{a}}$ & $1055.00^{\mathrm{a}}$ & $390.733^{\mathrm{a}}$ \\
\hline $\mathrm{T}_{4}$ & $40.33^{\mathrm{a}}$ & $786.70^{\mathrm{a}}$ & $302.467^{\mathrm{b}}$ \\
\hline L.S.D & 27.02 & 890.14 & 294.26 \\
\hline
\end{tabular}

Table 10b. (Aqueous Turmeric Extract)

\begin{tabular}{|l|l|l|l|}
\hline Treatments & Number of fruit & Mean fresh weight & Yield (kg/ha) \\
\hline $\mathrm{T}_{1}$ & $23.33^{\mathrm{a}}$ & $542.90^{\mathrm{a}}$ & $78.733^{\mathrm{b}}$ \\
\hline $\mathrm{T}_{2}$ & $28.33^{\mathrm{a}}$ & $579.70^{\mathrm{a}}$ & $214.666^{\mathrm{ab}}$ \\
\hline $\mathrm{T}_{3}$ & $44.67^{\mathrm{a}}$ & $940.80^{\mathrm{a}}$ & $385.600^{\mathrm{a}}$ \\
\hline $\mathrm{T}_{4}$ & $34.67^{\mathrm{a}}$ & $771.10^{\mathrm{a}}$ & $348.433^{\mathrm{ab}}$ \\
\hline L.S.D & 24.17 & 711.92 & 271.496 \\
\hline
\end{tabular}

Means in the same column, having the same letter according to LSD are not significant $(\mathrm{P}<0.05)$.

\section{REFERENCES}

[1] Adetuyi FO, Osagie AU, Adekunle AT (2008). Effect of Po- stharvest Storage Techniques on the Nutritional Properties of Benin Indigenous Okra Abelmoschus esculentus (L) Moench. Pakistan J. Nutrit. 7: 652-657 
[2] Ahmed F. F. Mansur A.E.M., Montasser, M.A.A., Merhead, M.A. and Monstafa E.A.M. (2013); "Response of Valencia Orange Trees to Foliar Application of Roselle, Turmeric and Seaweed Extracts" Journal of Applied Science Research. 9(1): 960-964.

[3] Akintoye HA, Adebayo AG, Aina OO (2011). Growth and yield response of okra intercropped with live mulches. Asian J. Agric. Res. 5: 146-153

[4] Akinyele BO, Temikotan T (2007). Effect of variation in soil textu- re on the vegetative and pod characteristics of okra (Abelmoschus esculentus (L.) Moench). Intern. J. Agric. Res. 2: 165-169

[5] Alonso, J., 2004. Tratado de Fitofarmocosy Nutraceutices, Barcelona Corpus., p: 395-403.

[6] Arapitsas P (2008). Identification and quantification of polyphe-nolic compounds from okra seeds and skins. Food Chem. 110:1041-1045.

[7] Bhdwaj, R.L., Dhashora, L.K. and Mukherjee, S., (2012); "Effect of Neem Leaf Extract and Benzyladenine on Post-Harvest Shelf Life of Orange (Citrus reticulate Blanco)"; J. Adv. Dev. Res.; Vol. 1(1); 32-37.

[8] Chawdhury, M.N.A.; Rahim, M.A.; Khalequzzaman, K.M; Humauan M.R.; and Alam, M.M.; (2007); "Effect of Plant Extracts and Time of Application on Incidence of Anthracnose, Yield and Quality of Mango" International Journal Sustain, Crop Production: 2(5): 59-68.

[9] Dilruba S, Hasanuzzaman M, Karim R, Nahar K (2009). Yield response of okra to different sowing time and application of growth hormones. J. Hortic. Sci. Ornamental Plants 1: 1014.

[10] Doijode SD (2001). Seed storage of horticultural crop. Food Pro- duct Press, New York, USA.

[11] Gopalan C, Sastri SBV, Balasubramanian S (2007). Nutritive value of Indian foods, National Institute of Nutrition (NIN), ICMR, India.

[12] Hafez, O.M., Saleh, M.A. and El-Lethy, S.R., (2013); "Response of Some Seedlings Olive Cultivars to Foliar Spray of Yeast and Garlic Extracts with or Without Vascular Arbuscular Mycorrhizal Fungi”; J. World Applied Sciences; 24:1119-1129

[13] Hanafy, M.S., Saadawy, F.M., Milad S.M.N. and Ali, R.M., (2012); "Effect of Some Natural Extracts on Growth and Chemical Constituents of Schefflera Arboricola Plants" J. of Hort. Sci. and ornamental plants; 4(1); 26-33

[14] Hegab, M.Y., Shaarawy, A.M.A. and El-Saida, S.A.G., (2005); "Effect of Algae Extract and Mono Potassium Phosphate on Growth and Fruiting of Balady Orange Trees" Underpress in Bull. Fac. of Agric. Cairo. Univ. 56:107-120

[15] Kahlon TS, Chapman MH, Smith GE (2007). In vitro binding of bile acids by okra beets asparagus eggplant turnips green be- ans carrots and cauliflower. Food Chem. 103: 676680.

[16] Karim, M.A. and Rahim, M.A. (2008); "Effects of Different Plant Extracts and Chemicals on Yield and Quality of Fruits of Four Mango Varieties. J. Agrofor. Environ. 2; 113-117

[17] Kumar R, Patil MB, Patil SR, Paschapur MS (2009). Evaluation of Abelmoschus esculentus mucilage as suspending agent in pa- racetamol suspension. Intern. J. Pharm Tech Res. 1: 658-665.

[18] Kumar S, Dagnoko S, Haougui A, Ratnadass A, Pasternak D, Ko- uame C (2010). Okra (Abelmoschus spp.) in West and Central Africa: potential and progress on its improvement. African J. Agric. Res. 5: 3590-3598

[19] Lengsfeld C, Titgemeyer F, Faller G, Hensel A (2004). Glyco- sylated compounds from okra inhibit adhesion of Helicobac- ter pylori to human gastric mucosa. J. Agric. Food Chem. 52:1495-1503

[20] Liu IM, Liou SS, Lan, TW, Hsu FL, Cheng JT (2005). Myrice- tin as the active principle of Abelmoschus moschatus to lower plasma glucosein streptozotocin-induced diabetic rats. Planta Medica 71: 617-621.

[21] Mohamed, A.Y. and Mohammed, H.H., (2013); "The Synergistic Effects of Using Turmeric with Various Nutrients on Fruiting of Sewy Date Palms" J. of Suez Canal Univ. 287 - 296. 
[22] Ndunguru J, Rajabu AC (2004). Effect of okra mosaic virus di- sease on the above-ground morphological yield components of okra in Tanzania. Scientia Horticulturae 99: 225-235.

[23] Norric, J.T. Brandon and Keathley, P.E., (2002); "Marin Plant Extracts Impact on Grape Yield and Quality"; Act a Hort. J.; 91; 93-100

[24] Okigbo, B., N. and A.O. Emoghene, (2003). Effect of leaf extracts of three plant species on Mycosphaerella fijiensis Morelet, the causal organism of black sigatoka disease of banana (Musa acuminata). Nigeria Journal of Plant Protection, 20: 101-110.

[25] Onuoha, G.N., Ibe, A. E., Madukwe, D. K. and Ibe, M. A. (2013). Functional Properties of Okra (Abelmoschus Esculentus) As Influenced By Storage Conditions in The Hot Humid Tropical Rainforest Zone Of Nigeria. International Journal of Tropical Agriculture and Food Systems, 7(2): $86-91$

[26] Owolarafe O.K., Shotonde HO (2004). Some physical properties of fresh okra fruit. J. Food Engin. 63: 299-302

[27] Purohit, C.K., (2000); "Effect of Pest Harvest Treatment with Plant Extract, Oil Emulsion and Plant Growth Regulators on Shelf Life of Mango" Cv. Langra. M.Sc. Thesis, Dept. of Hort. Rajasthan College of Agriculture, Udaipur, Rajasthan.

[28] Saifullah M, Rabbani MG (2009). Evaluation and characteriza- tion of okra (Abelmoschus esculentus L. Moench.) genotypes. SAARC J. Agric. 7: 92-99.

[29] Umar Musa tanko (2015). Influence of $\mathrm{N}$ - fertilizer application on one yield and yield component of two varieties of eggplant (Solanum melogena L.) In Anyigba, Kogi State Journal of Biology, Agriculture and Health Care.Vol 5. NO 17: 201-208.

[30] Varmudy V (2011). Marking survey need to boost okra exports. Department of economics, Vivekananda College, Puttur, Kar- nataka, India.

[31] Westerfield, R. (2008). Growing okra in the home garden. University of Georgia Cooperative Extension. Available at: http://www.caes.uga.edu/extension/tho.... [Accessed 27 February 15]. Free to access 